\title{
Multiple biomarkers of pollution effects in caged mussels on the Greek coastline
}

\author{
C. Tsangaris ${ }^{a},{ }^{*}$, K. Kormas ${ }^{b}$, E. Strogyloudi ${ }^{a}$, I. Hatzianestis ${ }^{a}$, C. Neofitou ${ }^{b}$, B. Andral ${ }^{c}$ and F. Galgani ${ }^{d}$ \\ a Institute of Oceanography, Hellenic Center for Marine Research, 46.7 klm, Athinon-Souniou Ave., P.O. Box 712, \\ 19013 Anavyssos, Greece \\ ${ }^{\mathrm{b}}$ Department of Ichthyology and Aquatic Environment, Faculty of Agricultural Sciences, University of Thessaly, \\ 38446 N. Ionia Volos, Greece \\ c IFREMER, Laboratoire Provence Azur Corse, BP 330, 83507 La Seyne sur Mer Cedex, France \\ d IFREMER, Laboratoire Environnement Ressources Languedoc Roussillon, BP 211, 34203 Sete Cedex, France \\ *: Corresponding author : C. Tsangaris, Tel.: + 3022910 76379; fax: + 3022910 76347, email address : \\ ctsangar@ath.hcmr.gr
}

\begin{abstract}
:
A suite of biomarkers was measured in caged mussels at areas impacted by different anthropogenic activities along the Greek coastline to assess biological effects of environmental pollution. Mussels were caged at coastal sites in the vicinity of major cities, in areas influenced by major industries, agricultural practices and in islands away from known sources of pollution. Biomarkers indicative of neurotoxicity (acetylcholinesterase, AchE), oxidative stress (catalase, CAT), phase II biotransformation of xenobiotics (glutathione S-transferase, GST), metal exposure (metallothioneins, MTs) and protein synthesis (RNA:DNA ratio) were measured to assess effects of various types of pollutants. AchE activity proved to be the most responsive biomarker with decreased values at sites influenced by agricultural, urban and industrial activities. Decreased CAT and GST activities and increased MTs levels were recorded at a number of anthropogenic-impacted sites. RNA:DNA ratio showed a biphasic response as both high and low values were found at impacted sites. Principal component analysis clearly distinguished sites receiving pollution inputs from non-polluted sites. The combination of the selected biomarkers used in caged mussels resulted useful in the assessment of the effects of environmental pollution.
\end{abstract}

Keywords: Biomarkers; AchE; CAT; GST; MTs; RNA:DNA ratio; Mytilus galloprovincialis; Mediterranean

\section{Introduction}

Biological effects of pollution are elements of major importance for the assessment of environmental quality since, by definition, pollution implies hazards to living resources. The effects of pollution can be measured at different levels of biological organization, from the molecular to the community level. Biomarkers are cellular, 
biochemical, molecular, or physiological changes that are measured in cells, body fluids, tissues, or organs within an organism and are indicative of xenobiotic exposure and/or effect of (Lam and Gray, 2003). Biomarkers range from general to specific, reflecting general stress or exposure to specific classes of environmental contaminants. Since changes at the organism level lead to changes at the population and community levels, biomarkers can be used as early warning signals of environmental disturbance (Walker et al., 2006). Therefore biomarkers are considered useful tools and are increasingly incorporated into environmental monitoring programs (e.g. Joint Monitoring Program of the OSPAR convention; MED POL, UNEP Mediterranean Biomonitoring Program) (Lam and Gray, 2003, Viarengo et al., 2007). The EU Water Framework Directive (WFD, Directive 2000/60/EC), that specified monitoring programs required to assess the achievement of good chemical and ecological status of water bodies, pointed out the importance of biological monitoring for the determination of water quality. Biomarkers, although not incorporated in the WFD, are among the emerging biological monitoring tools considered for use in monitoring programs necessary for the implementation of the WFD (Allan et al., 2006, Mills et al., 2007).

Mussels are commonly used as sentinel organisms in bio-monitoring studies (Andral et al., 2004; Viarengo et al., 2007). In addition to their wide geographical distribution and ability to accumulate contaminants, mussels can be easily caged at field sites. Wild mussels and/or transplanted mussels originating from a clean site are employed in bio-monitoring (Roméo et al., 2003; Bocquené et al, 2004; Andral et al., 2004; Pampanin et al., 2005a; Lehtonen et al. 2006). The parallel use of wild and caged mussels combines information on long-term effects and short-term effects of pollution in areas where they are naturally present. (Bolognesi et al., 2004; Pampanin et al., 2005a). Using caged mussels from a single population avoids bias related to the age and the reproductive status of the organisms that influence both contaminant bioaccumulation and biomarker responses and allows more accurate assessment of the real biological effects of contaminants over a predetermined exposure period (Andral et al., 2004; Viarengo et al., 2007).

The aim of this study was to assess biological effect/exposure of environmental pollution in Greek coastal waters over a wide spatial scale using a suite of biomarkers in caged mussels at several coastal areas impacted by different anthropogenic activities. Acetylholinesterase (AchE) is an enzyme involved in nerve impulse transmission and its inhibition is an established biomarker of neurotoxicity caused by exposure to organophosphate and carbamate pesticides (Fulton and Key, 2001) while recent studies suggest it may also indicate general stress (Lehtonen et al., 2006). Catalase (CAT) is an enzyme of the antioxidant defense used as a biomarker of oxidative stress that can be induced by a wide range of contaminants including organic xenobiotics and heavy metals (Livingstone, 2001, Akcha et al., 2000, Roméo et al., 2003). Glutathione-S-Transferases (GST) are the most important enzymes of the phase II biotrasformation of xenobiotics that have been shown to respond to organic contaminants (e.g. PCBs, chlorinated pesticides, PAHs; Cheung et al., 2001, 2002). Metallothioneins (MTs) are metal binding proteins involved in heavy metal detoxification and their induction is a biomarker of exposure to certain heavy metals, primarily Cd, Zn, Cu, Hg (Variengo et al., 1999). RNA:DNA ratio is a measure of protein synthesis that has been used as a biochemical biomarker of growth reflecting a general response to environmental stressors (Wo et al., 1999, Pottinger et al., 2002, Humphrey et al., 2007). While AchE, MTs, CAT and GST are commonly used biomarkers in Mytilus sp. (Roméo et al., 2003, Lehtonen et al., 2006) to our 
knowledge this is the first application of the RNA:DNA ratio as a biomarker of the effects of pollution in this genus.

\section{Materials and methods}

\subsection{Sampling areas and experimental design}

Eighteen sampling sites at areas influenced by different types of anthropogenic activities were selected along the Greek coastline (Fig 1). These included sites in the vicinity of major cities, Athens (S3) and Thessaloniki (S1 and S2), sites at areas influenced by major industries (S4, S5, S6), sites at areas influenced by agricultural practices (S7, S8, S9, S10, S11, S12) and sites in the Aegean Sea, near islands away from known sources of pollution that were as used as reference sites (S14, S15, S16, S17, S18) and on the island of Santorini (S13) where the cruise ship 'Sea Diamond' sank in April 2007 (Table 1). Pollutant concentrations previously reported in sediments at the selected areas are shown in Table 1.

Mussels were purchased from an aquaculture farm in NW Saronikos Gulf in May 2007. Mussels of approximately $60 \mathrm{~mm}$ shell length were sorted, placed in PVC cages (3 kg per cage) and maintained one week at the farm prior to immersion so that the mussels were able to fix themselves by their byssus threads. The transplantation was performed by the French oceanographic vessel ' $L$ ' Europe' and the Greek oceanographic vessel 'Philia'. During transplantation the mussel cages were kept on board in tanks provided with flowing seawater. The depth of the selected sites was between 20 to $30 \mathrm{~m}$. The mussel cages were immersed with a buoy at $8 \mathrm{~m}$ depth below the surface and were attached by a rope to a ballast of approximately $30 \mathrm{~kg}$ at the bottom. The mussels were recovered after three months by diving. The transplantation period did not coincide with the spawning season of the mussels in order to avoid influences of gamete release on bioaccumulation of pollutants and biomarker responses. Samples were conditioned immediately after collection on board. In one batch of mussels, whole soft tissues were removed from the shells and stored at $-20^{\circ}$ for condition index (pooled sample of 30-40 individuals per site) and RNA:DNA ratio (3 pooled samples of 3-5 individuals per site) measurements. In a second batch of mussels, gills and digestive glands were dissected and pooled samples from 6 individuals (5 samples per site) were frozen and stored in liquid nitrogen for AchE, CAT, GST and MTs measurements. When transferred to the laboratory samples remained at $-80^{\circ} \mathrm{C}$ until analysis.

\subsection{Physiological status of transplanted mussels}

Condition index (C.I.) was determined as an indicator of the physiological status of the mussels. C.I. is an ecophysiological measure of the health status of the animals that summarizes their physiological activity (growth, reproduction, secretion etc.) under given environmental conditions. The samples were pre-processed according to standardized procedures (Andral et al., 2004). Dissected whole soft tissues from 30-40 individuals were pooled into a composed sample and then lyophilized. Shells were dried at $60{ }^{\circ} \mathrm{C}$ in the oven for $48 \mathrm{~h}$ and then weighed. Flesh was weighed after freezedrying. The ratio of dry flesh weight to dry shell weight (FW/SW X 100) was used to determine C.I. for each sample. During the period of sexual dormancy, this quotient is a good indicator of mollusc growth. 


\subsection{AchE activity}

Gill tissues were homogenized using a Potter-Elvehjem homogenizer (Heidolph Electro GmbH, Kelheim, Germany) in 1:2 (w:v) 0.1M Tris-HCl buffer containing $0.1 \%$ TRITON X 100, pH 7. Homogenates were centrifuged at $10,000 \mathrm{~g}$ for $20 \mathrm{~min}$. All preparation procedures were carried out at $4^{\circ} \mathrm{C}$. AchE activity was assayed by the method of Ellman (Ellman et al., 1961) adapted to microplate reading by Bocquené et al. (1993) on an Assys Digiscan reader 340. Total protein content was measured using Bovine Serum Albumin (BSA) as a standard (Bradford, 1976). Enzyme activity was expressed as U/mg proteins. One unit (U) of AchE activity is the amount of enzyme, which causes a variation of 0.001 in optical density per minute.

\subsection{CAT activity}

Digestive glands were homogenized using a Potter-Elvehjem homogenizer in 1:5 (w:v) $100 \mathrm{mM} \mathrm{KH}{ }_{2} \mathrm{PO}_{4} / \mathrm{K}_{2} \mathrm{HPO}_{4}$, $\mathrm{pH}$ 7.4. Homogenates were centrifuged at $10,000 \mathrm{~g}$ for $30 \mathrm{~min}$. All preparation procedures were carried out at $4^{\circ} \mathrm{C}$. CAT activity was measured by the method of Cohen et al. (1996) by the loss of $\mathrm{H}_{2} \mathrm{O}_{2}$ that was measured calorimetrically with ferrous ions and thiocyanate on a microplate reader. CAT activity was determined by the difference in the absorbance at $490 \mathrm{~nm}$ per unit of time. CAT activity results are expressed in terms of the first order reaction rate constant (k) and protein content as follows: U/mg proteins $=\mathrm{k} / \mathrm{mg}$ proteins $=[\mathrm{ln}$ $\left.\left(A_{1} / A_{2}\right) /\left(t_{2}-t_{1}\right)\right] / m g$ proteins where $\ln$ is the natural $\log , A_{1}$ and $A_{2}$ are the observed mean absorbance at $490 \mathrm{~nm}$ at two time points, $t_{1}=1 \mathrm{~min}$ and $\mathrm{t}_{2}=4 \mathrm{~min}$.

\subsection{GST activity}

Preparation of digestive gland tissue extracts were as described for CAT. GST was measured by the method of Habig and Jacoby (1981) with 1-chloro-2,4dinitrobenzene (CDNB) as a conjugation substrate, adapted to microplate reading by Mc Farland et al. (1999). Activity was expressed as nmol conjugate/min/mg proteins.

\subsection{MTs content}

MTs concentration was measured in digestive glands according to Viarengo et al. (1997) on a Perkin Elmer UV/VIS spectrometer Lamda 20. The method is based on the estimation of the sulphydryl content of MTs proteins by spectrophotometric determination of the -SH groups using Ellman's reagent. MTs concentration was calculated utilizing reduced glutathione (GSH) as a reference standard and expressed as $\mu \mathrm{g}$ MTs/g wet weight tissue.

\subsection{RNA:DNA}

Nucleic acids were quantified spectrophotometrically in whole soft tissue.To reduce variability the whole soft tissue from 3-5 specimens were pooled for each analysis. Samples were homogenized with a mortar and pestle in liquid nitrogen and ca. $1.5 \mathrm{~g}$ of the homogenized material was used for nucleic acid extraction with the Qiagen RNA/DNA kit according to the manufacturer's instructions (Qiagen, USA). The concentration and purity of the extracted nucleic acids were determined with the NanoDrop ND-1000 (NanoDrop Technologies, USA). RNA:DNA was calculated as the ratio of mean RNA (ng/mg) to mean DNA (ng/mg) of 3 pooled samples per site.

\subsection{Statistical analysis}

Data are presented as mean \pm standard error of the mean. The Kolmogorov-Smirnoff test and Levene's test were applied to test normal distribution and homogeneity of 
variance respectively. One-way analysis of variance (ANOVA) followed by the Fisher's LSD multiple comparison test was applied to determine differences between sites when homogeneity of variance was assumed (AchE, MTs), while when variances were not equal (GST, CAT) the Games-Howell test was used. Significance level was set at $\mathrm{P}<0.05$.

Principal Component Analysis (PCA) was performed to discriminate sites by integration of biomarkers according to principal axes. Biomarkers (AchE, CAT, MTs, GST, RNA:DNA) and C.I. were the variables used in PCA. PCA was applied to mean values of biomarkers and values from pooled samples of C.I. at each site. PCA requires that all the sites have values for all the parameters and as we did not have MTs results for S8, S9, S11 and S17 these sites were not analyzed in PCA. Statistical analysis was performed using SPSS (univariate methods) and Statgraphics (PCA).

\section{Results}

\subsection{I.}

C.I. overall ranged from 4.2 to 10.9 (Fig 2). Higher C.I. values ranging from 7.7 to 10.9 were recorded in mussels caged at S1, S2, S4, S7 and S12. Variation in the C.I. at the other sites was limited and values ranged between 4.2 at S18 and 6.9 at S3.

\subsection{AchE}

AchE activities ranged from 165 to $235 \mathrm{U} / \mathrm{mg}$ proteins at sites influenced by anthropogenic activities (S1, S2, S3, S4, S5, S6, S7, S10, S11) and from 278 to 305 $\mathrm{U} / \mathrm{mg}$ proteins at the reference sites (S14, S15, S16, S17, S18) (Fig 3). AchE activities recorded in mussels at S8, S9, S12 and S13 sites, were similar to those at the reference sites (261-326 U/mg proteins). Significantly lower AchE activities were found in mussels caged at S1, S2, S3, S4, S5, S6, S7, 10 and S11 sites compared to the reference sites and/or S8, S12 and S13 sites.

\subsection{CAT}

Overall CAT activities varied from 0.7 to $3.6 \mathrm{U} / \mathrm{mg}$ proteins (Fig 4). CAT activities were generally lower in mussels caged at sites influenced by anthropogenic activities (0.7-1.8 U/mg proteins) compared to reference sites (1.9-3.4 U/mg proteins) with the exception of S4, S8, S9, S12 and S18 sites. Significantly lower CAT activities were recorded at S1, S2, S6, S7, S11, S13 and S18 sites compared to S17 reference site and/or S16 reference site. CAT activities at S1 and S13 were also lower than those at S14 reference site and S12.

\subsection{GST}

Overall GST activities ranged from 35.9 to $70.4 \mathrm{nmol} / \mathrm{min} / \mathrm{mg}$ proteins (Fig 5). GST activities did not show a clear trend at sites influenced by anthropogenic activities, although low values were noted at a few impacted sites. The lowest GST activities recorded in mussels caged at S5 site were significantly different than those at S17 reference site and also S8, S10, S12 and S13 sites. Furthermore significantly lower GST activities were found at S3, S7 and S18 reference site compared to S17 reference site, S10 and/or S12 sites. 


\subsection{MTs}

MT levels ranged between 152 and $225 \mu \mathrm{g} / \mathrm{g}$ tissue at four of the anthropogenicallyimpacted sites (S3, S6, S7, S13), and between 94 and $138 \mu \mathrm{g} / \mathrm{g}$ tissue at all other sites (Fig 6). MTs were significantly higher in mussels at S3, S6, S7 and S13 compared to all other sites with the exception of S18 reference site. MTs at S18 reference site were significantly higher with respect to the sites showing the lowest MTs levels i.e. S1, S5, S10 and S15.

\subsection{RNA:DNA}

RNA (ng/mg) and DNA (ng/mg) concentrations used for the calculation of RNA:DNA ratio at each site are shown in Table 2.

As regards RNA:DNA ratio, a distinct response at sites influenced by anthropogenic activities was not evident (Fig 7). Coefficient of variation varied between 0.1 and $14.6 \%$ (average 3.3\%). Overall RNA:DNA ranged from 0.01 to 2.34. Highest RNA:DNA levels were found at S4 and S5 (2.34 and 1.72 respectively) and lowest levels at S1, S2, S6, S7, S11, S12 and S16 sites (0.01-0.08). All other sites showed levels of RNA:DNA that ranged between 0.15 to 1.28 .

\subsection{PCA}

PCA of biomarkers and C.I. produced three principal components that accounted for $76.3 \%$ of the total variance. PCs can be interpreted based on the loadings (coefficients in the linear combinations of variables making up the PCs), which explain how strongly the original variables correlate to the respective PC (Table 3). PC1 explained $31.3 \%$ of the total variance and was influenced by the C.I. on the positive part and AchE and GST on the negative part. PC2 explained $25.1 \%$ of the total variance and was correlated with MTs on the positive part and CAT and RNA:DNA on the negative part. PC3 represented $19.9 \%$ of the total variance and was positively correlated with MTs and RNA:DNA and negatively correlated with GST and C.I.

The plot of variable vectors for the two dominant components PC1 and PC2 that explained $56.4 \%$ of the total variance is shown in Figure 8A. The plot of scores for different sites for the two dominant components PC1 and PC2 separated four groups of sites (Figure 8B). All reference sites S14, S15, S16, S17 and S18 were grouped together along with S10 and S12. The anthropogenically-impacted sites were separated into three groups: (a) S1 and S2, (b) S4 and S5, and (c) S3, S6, S7 and S13. To examine how the introduction of each variable modifies PCA results, six additional PCA were applied excluding variables from the data set (not shown). PCA applied on biomarkers excluding C.I. produced a similar pattern but separation of groups was less distinct. Further exclusion of CAT and GST also led to a similar but less distinct separation, while exclusion of AchE, MTs or RNA:DNA ratio modified the site separation and did not clearly discriminate the group of reference sites.

\section{Discussion}

This study applied a suite of biomarkers in mussels to assess pollution effects in Greek coastal waters. A standardized technique of caging mussels in the open sea was used in order to avoid bias related to genetic differences as well as the previous physiological and reproductive condition of the animals (Andral et al., 2004). However, variations in environmental factors such as temperature, salinity and food availability among sites would influence the physiological state of the animals. Variations in the physiological state of mussels as shown by C.I. results were 
generally in accordance with the trophic characteristics of the sites with high values at areas where food is abundant and mussel culture is intense i.e.Thermaikos Gulf, Nestos estuary, Maliakos Gulf and N. Evoikos Gulf (SoHelME, 2005) and low values at the reference sites in the Aegean Sea where waters are oligotrophic (Ignatiades, 2005). These findings suggest that C.I. was influenced by food availability although possible advanced spawning induced by natural or pollution stress resulting in weight loss may also have affected C.I. Nevertheless, differences in the C.I. did not mask biomarker responses to pollution since biomarker values overall varied between anthropogenic impacted and reference sites.

AchE activity resulted the most responsive biomarker showing lower levels at nine sites influenced by anthropogenic activities compared to the reference sites. AchE inhibition has been widely used as a biomarker of neurotoxic effects by organophosphate and carbamate pesticides (Fulton and Key, 2001). Recent studies have shown that other types of pollutants such as heavy metals, surfactants and PAHs (Guilhermino et al., 1998, Achka et al., 2000, Elumalai et al., 2002) may also inhibit AchE activity. AchE inhibition has thus been suggested as indicative of general stress (Lehtonen et al., 2006). In accordance, our results showed decreased AchE activities not only at sites in areas influenced by agricultural practices where pesticide contamination would be expected (S2, S7, S10, S11) but also at sites in areas receiving urban and industrial wastes (S1, S3, S4, S5, S6) where a wide variety of pollutants are found (Voutsinou-Taliadouri and Varnavas, 1993, Papatheodorou et al., 1999, Hatzianestis et al., 2000, Poulos et al., 2000, Angelidis and Aloupi 2000, Hatzianestis et al., 2003, Hatzianestis and Botsou, 2005, 2006, Skoullos et al., 2007).

CAT response to toxic chemicals shows a bell-shaped trend with an initial increase in activity due to enzyme induction followed by a decrease in activity due to enhanced catabolic rate and/or direct inhibition by toxic chemicals (Viarengo et al., 2007). Such trends in CAT activities can be found in mussels at polluted sites according to the levels and duration of pollutant exposure (Regoli and Principatto, 1995, Nasci et al., 2002, Roméo et al., 2003, Regoli et al., 2004, Nesto et al., 2004, Pampanin et al., 2005b). Regoli et al. (2004) showed an increase in CAT activity during the first two weeks of mussel transplantation at an industrialized harbour of NW Italy followed by a progressive decrease. Decreased CAT activities in mussels transplanted at polluted sites have been found in addition to a reduced capability of neutralizing Reactive Oxygen Species (ROS) and an increased susceptibility to oxidative stress (Pampanin et al., 2005b). Accordingly, the low CAT activities in mussels transplanted at impacted sites of this study can be associated with difficulty to compensate to oxidative stress. CAT responds to a wide range of contaminants capable of ROS production such as PAHs, PCBs, heavy metals, pesticides (Krishnakumar et al., 1997, Regoli and Principato, 1995, Akcha et al., 2000, Roméo et al., 2003, Khessiba et al., 2005) thus CAT responses were evident at sites receiving different pollutant inputs (S1, S2, S6, S7, S11 and S13).

GST response to toxic chemicals follows a similar bell-shaped trend as CAT (Viarengo et al., 2007) hence increased and decreased enzyme activities have been reported in polluted areas (Roméo et al., 2003, Regoli et al., 2004, Bocquené et al., 2004, Bebianno et al., 2007). GST is induced by organic contaminants as part of the phase II biotransformation pathway (Sheenan and Power, 1999) while GST inhibition has been indicated as more aspecific response to chemical challenge (Regoli et al., 2003). In this study, GST responses did not show a clear trend although reduced activities were found at three of the impacted sites (S3, S5 and S7). 
MTs induction is a well-recognized biomarker of heavy metal exposure that is commonly applied in pollution monitoring programs (Viarengo et al., 1999, Viarengo et al, 2007). MTs levels are largely influenced by factors such as reproductive condition, duration of exposure, previous exposure and environmental parameters thus the use of transplanted mussels is suggested as the most suitable approach for the application of MTs as a biomarker of heavy metal exposure (Viarengo et al., 1999). Increased MTs values were found only at four of the impacted sites: S3, S6, S7 and S13. This is in agreement with generally low heavy metal levels in the tissues of mussels and only few differences among sites including increased $\mathrm{Cu}$ and/or Cd levels at S3, S6 and S7 (Andral, unpublished results).

Controversially, low CAT activities, low GST activities and high MTs levels were recorded at S18 reference site in the South Aegean Sea where the lowest C.I values were recorded, reflecting stress possibly caused by natural factors such as temperature, salinity, food availability etc. as wild mussels are not present in this area. Similar responses were recorded at S13 site also situated in the South Aegean Sea. Whether biomarker responses at S13 site were due to natural environmental factors or pollutants emerging from the shipwreck of the 'Sea Diamond' cruise ship two months prior mussel transplantation in this area could not be distinguished. On the other hand, at S8, S9 and S12 sites initially regarded as potentially impacted, AchE, CAT, GST and MTs values were similar to those at the reference sites suggesting the degree of impact is low. In fact contaminant levels reported in sediments at these areas are lower than at the other impacted sites (Table 1).

The RNA:DNA ratio provides an estimate of nutritional condition and recent protein synthesis (Buckley et al., 1999). Consequently, RNA:DNA ratios have been used to assess the condition and growth of bivalves (Norkko et al., 2006, Menge et al., 2007) but applications for the assessment of pollution effects are limited (Roesijadi et al., 1995, De Luca-Abbot, 2001, Lannig et al., 2006). During exposure to low pollution protein synthesis is known to increase due to induction of proteins involved in the protection of the cell against harmful conditions, such as stress proteins, MTs, antioxidant enzymes and biotransformation enzymes, which is expected to reflect in elevated transcriptional activity and thus higher RNA:DNA ratios (Lannig et al., 2006). At high pollution stress however, protein synthesis can be suppressed indicating disturbance of normal metabolic processes (Pottinger et al., 2002). Therefore increase or decrease in protein synthesis and thus RNA:DNA ratios can be expected as a result of pollutant exposure depending on the stress level. Our results indicate a biphasic response of RNA:DNA ratio to stress as both high and low values were found at impacted sites. At reference sites with the exception of S16, DNA:RNA ratio levels were in the mid range for this study as they were also at S8, S9 and S10 where most other biomarker values were similar to the reference sites. At impacted sites either very high or very low DNA:RNA ratio levels were found indicating increased or decreased protein synthesis respectively. These results indicate that changes in RNA:DNA ratio may reflect pollution stress but the use of RNA:DNA ratio as a biomarker must be used with caution and appropriate reference values must be established.

For integration of biomarker responses, PCA was applied to differentiate groups of sites as a function of principal components. The two dominant components strongly corresponded to AchE and C.I (PC1) and MTs, CAT and RNA:DNA (PC2). PCA clearly distinguished reference from impacted sites since all reference sites (S14, S15, S16 and S18) were grouped together by PC1 and PC2 reflecting similar biomarker responses. S10 and S12 were also grouped with the reference sites. The impacted sites 
were separated into three groups by combinations of different biomarker responses: (a) S1 and S2, (b) S4 and S5, and (c) S3, S6, S7 and S13. These results suggest that combinations of different biomarker responses reflect different types of pollution in each group of the impacted sites. This is also supported by the separation of groups of impacted sites according to geographical areas. Groups (a) and (b) that include sites in the same geographical area ((a): Thermaikos Gulf (b): Evoikos gulf,) are clearly distinct from group (c) that includes sites at different regions (Maliakos Gulf, Korinthiakos Gulf, Saronikos Gulf, Aegean Sea) and is widespread. It is also important to point out that group (b) sites, S4 and S5, although in the same geographical area, receive industrial inputs from different industries but are both characterized by high concentrations of heavy metals such as $\mathrm{Cr}$ and Ni (VoutsinouTaliadouri and Varnavas, 1993, Angelidis and Aloupi 2000). AchE, MTs and RNA:DNA appeared the most relevant end points applied since their introduction in the PCA was crucial for discriminating the groups of sites.

In conclusion the present study showed that a combination of biomarker responses representing different biological endpoints in caged mussels distinguished sites receiving pollution inputs by various anthropogenic activities from non-impacted sites in Greek coastal waters and are thus useful for the assessment of environmental pollution effects. Therefore, it is important to include several reference sites in field studies as certain biomarkers may show biphasic responses or can be influenced by environmental factors other than pollutant exposure. A clear picture of reference values must be established for interpretation of biomarker results.

\section{Acknowledgements}

This study was financed by the INTEREG IIIB Medocc EU Project MYTIMED. The authors greatly appreciate the assistance of the crews of the oceanographic vessels ' $\mathrm{L}$ ' Europe' and 'Philia'. We also thank C. Tomasino, C. Ravel, N. Ganzin, P. Vavilis, H. Thebault, E. Emery for their valuable assistance in field work and sample preparation and S. Tsoumpana, and V. Gioni for their assistance with enzyme analyses.

\section{References}

Akcha, F., Izuel, C., Venier, P., Budzinski, H., Burgeot, T., Narbonne J-F, 2000. Enzymatic biomarker measurement and study of DNA adduct formation in benzo[a]pyrene-contaminated mussels, Mytilus galloprovincialis. Aquat. Toxicol. 49, 269-287.

Allan, I.J., Vrana, B., Greenwood, R., Mills, G.A., Roig, B., Gonzalez, C., 2006. A "toolbox" for biological and chemical monitoring requirements for the European Union's Water Framework Directive. Talanta 69, 302-322.

Anagnostou, Ch., Kaberi, H., 1995. An environmental quality approach of the sediments of Maliakos gulf (Central Greece) based on heavy metal levels. Water Pollution III: Modelling, Measuring and Prediction, L.C.Wrobel and P.Latinopoulos (eds), Computational Mechanics Publications, Southampton, UK, pp.423-430.

Andral, B., Stanisiere, J.Y., Sauzade, D., Damier, E., Thebault, H., Galgani, F., Boissery, P., 2004. Monitoring chemical contamination levels in the Mediterranean based on the use of mussel caging. Mar. Pollut. Bull. 49, 704-712.

Angelidis, M.O. Aloupi, M., 2000. Geochemical study of coastal sediments influenced by river-transported pollution: Southern Evoikos Gulf, Greece. Mar. Pollut. Bull. 40, 77-82. 
Bebianno,, M.J., Lopes,, B., Guerra, L., Hoarau, P., Ferreira, A.M., 2007. Glutathione S-tranferases and cytochrome P450 activities in Mytilus galloprovincialis from the South coast of Portugal: Effect of abiotic factors. Environ. Int. 33, 550-558.

Bocquené, G., Chantereau, S., Clérendeau, C., Beausir, E., Ménard, D., Raffin, B., Minier, C., Burgeot, T., Leszkowicz, A. P., Narbonne, J-F., 2004. Biological effects of the "Erika" oil spill on the common mussel (Mytilus edulis). Aquat. Living Resour. 17, 309-316.

Bocquené, G., Galgani, F., Burgeot, T., Le Dean, L., Truquet, P., 1993. Acetylcholinesterase levels in marine organisms along French coasts. Mar. Pollut. Bull. 26, 101-106.

Bolognesi, C., Frenzilli, G., Lasagna, C., Perrone, E., Roggie, P. 2004. Genotoxicity biomarkers in Mytilus galloprovincialis: wild versus caged mussels. Mutat. Res. 552 (2004) 153-162

Bradford, M., 1976. A rapid and sensitive method for the quantitation of microgram quantities of protein utilizing the principle of protein-dye binding. Anal. Biochem. 772, 248-64.

Buckley, L., Caldarone, E., Ong, T.-L., 1999. RNA-DNA ratio and other nucleic acid-based indicators for growth and condition of marine fishes. Hydrobiologia 401, 265-277.

Cheung, C.C.C., Zheng, G.J, Lam, P.K.S., Richardson, B.J., 2002. Relationships between tissue concentrations of chlorinated hydrocarbons (polychlorinated biphenyls and chlorinated pesticides) and antioxidative responses of marine mussels, Perna viridis. Mar. Pollut. Bull. 45, 181-191.

Cheung, C.C.C., Zheng, G.J., Li, A.M.Y., Richardson, B.J., Lam, P.K.S., 2001. Relationships between tissue concentrations of polycyclic aromatic hydrocarbons and antioxidative responses of marine mussels, Perna viridis. Aquat. Toxicol. 52, 189203

Cohen, G., Kim, M., Ogwu, V., 1996. A modified catalase assay suitable for a plate reader and for the analysis of brain cell cultures. J. Neurosci. Methods 67, 53-56.

Cotou, E., Pancucci-Papadopulou, M.A., Hatzianestis, I., 2002. Microtox ${ }^{\circledR}$ Solid-phase for marine sediments: A case study in Nestos river region (North Aegean, Greece). VI International Conference on Protection and Restoration of the environment. Skiathos, Greece, 1-5 July 2002, proceedings, Vol. II, pp. 773-778.

De Luca-Abbot, S., 2001. Biomarkers of sublethal stress in the soft-sediment bivalve Austrovenus stutchburyi exposed in situ to contaminated sediment in an urban New Zealand harbour. Mar. Pollut. Bull. 42, 817-825.

Ellman, G.L., Courtney, K.D, Andres, V.Jr, Featherstone, R.M, 1961. A new and rapid colorimeric determination of acetylcholinesterase activity, Biochem. Pharmacol. 7, 88-95.

Elumalai, M., Antunes, C., Guilhermino, L., 2002. Single metals and their mixtures on selected enzymes of Carcinus maenas. Water, Air, Soil Pollut. 141, 273-280.

Fulton, M.H., Key. P.B., 2001. Acetylcholinesterase inhibition in estuarine fish and invertebrates as an indicator of organophosphorus insecticide exposure and effects. Environ. Toxicol. Chem. 20, 37-45.

Guilhermino, L., Barros, P., Silva, M. C., Soares, A.M.V.M., 1998. 'Should the use of cholinesterases as a specific biomarker for organophosphate and carbamate pesticides be questioned?'Biomarkers 3, 157-163.

Habig, W.H., Jakoby, W.B., 1981. Assays for the differentiation of glutathione Stransferases. Meth. Enzymol. 77, 398-405. 
Hatzianestis, I., Botsou, F., 2006. Distribution of hydrocarbons and organochlorine compounds in sediments from Korinthiakos Gulf. 8th Hellenic Symposium on Oceanography and Fisheries, Thessaloniki, Greece, 4-8 June 2006. Abstracts p. 68.

Hatzianestis, I., Botsou, F., 2005. Distribution of organochlorinated compounds in Saronikos gulf sediments. $9^{\text {th }}$ International Conference on Environmental Science and Technology, proceedings, pp. B331-336, 1-3 September 2005, Rhodos, Greece Hatzianestis, I., Botsou, F., Sifnioti, P., Rigas F. 2005. PAH levels and distribution in sediments from Northern Evoikos Gulf, Greece. 13th International Symposium on Environmental Pollution and its Impact on Life in the Mediterranean Region, 8-12 October, Thessaloniki, Greece

Hatzianestis, I., Hantzi, A., Sklivagou, E., Rigas, F., 2003. Distribution and origin of aliphatic and polycyclic aromatic hydrocarbons in Saronikos Gulf sediments. 8th International Conference on Environmental Science and Technology, Proceedings, pp. 310-317, 8-10 September 2003, Lemnos.

Hatzianestis, I., Sklivagou, E., Georgakopoulou, E., 2000. Organic contaminants in sediments and mussels from Thermaikos gulf, Greece. Toxicol. Environ. Chem. 74, 203-215.

HCMR, 2008a. Monitoring of the quality of the marine environment in Thessaloniki bay. Final Technical report, Pagou, K (ed), Anavyssos.

HCMR, 2008b. Impact study on marine biota and sediments, Technical report, Catsiki, A (ed), Anavyssos.

HCMR, 2008c. Study of the short- and long-term effects of the pollution caused by the accident of the cruise ship sea diamond in Athinios bay in Santorini island, Technical report, Hatzianestis, I. (ed), Anavyssos.

HCMR, 2007a. Monitoring of the quality of the marine environment in Messiniakos gulf during 2006-2010. Technical report, Hatzianestis I. (ed), Anavyssos.

HCMR, 2007b. Study of the short-term effects of the pollution caused by the accident of the cruise ship sea diamond in Athinios bay in Santorini island, Technical report, Hatzianestis, I. (ed), Anavyssos.

HCMR, 2004. Study of the coastal marine ecosystem of North Rhodos. Technical report, Chatiris, G. (ed), Rhodos.

Humphrey, C.A., Codi King, S., Klumpp, D.W., 2007. A multibiomarker approach in barramundi (Lates calcarifer) to measure exposure to contaminants in estuaries of tropical North Queensland. Mar. Pollut. Bull. 54,1569-1581.

Ignatiades, L., 2005. Scaling the trophic status of the Aegean Sea, Eastern Mediterranean. J. Sea Res. 54, 51- 57.

Khessiba, A., Roméo, M., Aıssa, P., 2005. Effects of some environmental parameters on catalase activity measured in the mussel (Mytilus galloprovincialis) exposed to lindane. Environ. Pollut. 133, 275-281.

Karageorgis, A., Hatzianestis I., 2003. Surface sediment chemistry in the Olympic games 2004 Sailing Center (Saronikos Gulf). Medit. Mar. Sci. 4, 5-22

Krishnakumar, P.K., Casillas, E., Varanasi, U., 1997. Cytochemical Responses in the digestive tissue of Mytilus edulis complex exposed to microencapsulated PAHs or PCBs. Comp. Biochem. Physiol. 118C, 11-18.

Laboratory Network of the Environmental Quality monitoring of the Hellenic Seas, 2006. Environmental Quality Monitoring Program of the Hellenic Seas, Final Technical Report, Scoullos M. (ed) Athens

Lam, P.K.S., Gray, J.S., 2003. The use of biomarkers in environmental monitoring programmes. Mar. Pollut. Bull. 46, 182-186 
Lannig, G., Flores, J.F., Sokolova, I.M., 2006. Temperature-dependent stress response in oysters, Crassostrea virginica: Pollution reduces temperature tolerance in oysters. Aquat. Toxicol. 79, 278-287.

Lehtonen, K.K., Schiedek, D., Köhler, A.,. Lang, T., Vuorinen, P.J., Förlin, L., Barŝiené, J., Pempkowiak, J., Gercken. J., 2006. The BEEP project in the Baltic Sea: Overview of results and outline for a regional biological effects monitoring strategy. Mar. Pollut. Bull. 53, 523-537.

Lelekis, J., Petalas, S., Hatzianestis, I., Sklivagou E., 2001. Determination of anthropogenic organic compounds in the sediments of a deltaic-coastal area. The case of Igoumenitsa Gulf and Kalamas river. $7^{\text {th }}$ International Conference on Environmental Science and Technology, 3-6 September, Syros, Greece, proceedings, Vol. C', pp. 251-257

Livingstone, D.R., 2001. Contaminant-stimulated reactive oxygen species production and oxidative damage in aquatic organisms. Mar. Pollut. Bull. 42, 656-666.

McFarland, V.A., Inouye, L.S., Lutz, C.H., Jarvis, A.S., Clarke, J.U, McCant, D.D., 1999. Biomarkers of oxidative stress and genotoxicity in livers off field-collected brown bullhead, Ameiurus nebulosus. Arch. Environ. Contam. Toxicol. 37, 236-241.

Menge, B.A., Daley, B.A., Sanford, E., Dahlhoff, E.P., Lubchenco, J., 2007. Mussel zonation in New Zealand: an integrative eco-physiological approach. Mar. Ecol. Prog. Ser. 345, 129-140.

Mills, G.A., Greenwood, R., Gonzalez, C., 2007. Environmental monitoring within the Water Framework Directive (WFD). Trends Anal. Chem. 26, 450-453.

Nasci, C., Nesto, N., Monteduro, R.A., Da Ros, L., 2002. Field application of biochemical markers and a physiological index in the mussel, Mytilus galloprovincialis: transplantation and biomonitoring studies in the lagoon of Venice (NE Italy). Mar. Environ. Res. 54, 811-816.

Nesto, N., Bertoldo, M., Nasci, C., Da Ros, L., 2004. Spatial and temporal variation of biomarkers in mussels (Mytilus galloprovincialis) from the Lagoon of Venice, Italy. Mar. Environ. Res. 58, 287-291

Norkko, J., Thrush, S.F., Wells. R.M.G., 2006. Indicators of short-term growth in bivalves: Detecting environmental change across ecological scales. J. Exp. Mar. Biol. Ecol. 337, 38-48.

Pampanin, D.M., Camus, L., Gomiero, A., Marangon, I., Volpato, E., Nasci, C., 2005a. Susceptibility to oxidative stress of mussels (Mytilus galloprovincialis) in the Venice Lagoon (Italy). Mar. Pollut. Bull. 50, 1548-1557.

Pampanin, D.M., Volpato, E., Marangon, I., Nasci, C., 2005b. Physiological measurements from native and transplanted mussel (Mytilus galloprovincialis) in the canals of Venice. Survival in air and condition index. Comp. Biochem. Physiol. 140A, 41- 52.

Papatheodorou, G., Lyberis, E., Ferentinos, G., 1999. Use of factor analysis to study the distribution of metalliferous bauxitic tailings in the seabed of the Gulf of Corinth, Greece. Nat. Resour. Res. 8, 277-286.

Pottinger, T.G., Carrick, T.R., Yeomans W.E., 2002. The three-spined stickleback as an environmental sentinel: effects of stressors on whole-body physiological indices. J Fish Biol. 61, 207-229.

Poulos, S.E., Chronis, G.Th., Collins, M.B., Lykousis V., 2000. Thermaikos Gulf Coastal System, NW Aegean Sea: an overview of water sediment fluxes in relation to air-land-ocean interactions and human activities. J. Marine. Syst. 25, 47-76.

Regoli, F., Frenzilli, G., Bocchetti, R., Annarumma, F., Scarcelli, V., Fattorini, D., Nigro, M., 2004. Time-course variations of oxyradical metabolism, DNA integrity 
and lysosomal stability in mussels, Mytilus galloprovincialis, during a field translocation experiment. Aquat. Toxicol. 68, 167-178.

Regoli, F., Principato, G., 1995. Glutathione, glutathione-dependent and antioxidant enzymes in mussel, Mytilus galloprovincialis, exposed to metals under field and laboratory conditions implications or the use of biochemical biomarkers. Aquat. Toxicol. 31, 143-164.

Regoli, F.,Winston, G.W., Gorbi, S., Frenzilli, G., Nigro, M., Corsi, I., Focardi, S., 2003. Integrating enzymatic responses to organic chemical exposure with total oxyradical absorbing capacity and DNA damage in the European eel Anguilla anguilla. Environ. Toxicol. Chem. 22, 56-65.

Roesijadi, G., Hansen, K.M., Fuentes, M.E., 1995. Cadmium-Induced Expression of Metallothionein and suppression of RNA to DNA ratios during molluscan development. Toxicol. Appl. Pharmacol. 133, 130-138.

Roméo, M., Hoarau, P., Garello, G., Gnassia-Barelli, M., Girard, J.P., 2003. Mussel transplantation and biomarkers as useful tools for assessing water quality in the NW Mediterranean. Environ. Pollut. 122, 369-378.

Scoullos, M.J., Sakellari, A., Giannopoulou, K., 2007. Dissolved and particulate trace metal levels in the Saronikos Gulf, Greece, in 2004. The impact of the primary Wastewater Treatment Plant of Psittalia. Desalination 210, 98-109.

Sheehan, D., Power A., 1999. Effects of seasonality on xenobiotic and antioxidant defence mechanisms of bivalve molluscs Comp. Biochem. Physiol. C 123, 193-199.

SoHelME, 2005 State of the Hellenic Marine Environment. E. Papathanassiou \& A. Zenetos (eds). HCMR Publ, 360 pp.

Viarengo, A., Burlando, B., Dondero, F., Marro, A., Fabbri, R., 1999. Metallothionein as a tool in biomonitoring programmes. Biomarkers 4, 455-466.

Viarengo, A., Ponzano, E., Dondero, F., Fabbri, R., 1997. A simple spectrophotometric method for metallothionein evaluation in marine organisms: Application to mediterranean and antartic molluscs. Mar. Environ. Res. 44, 69-84.

Viarengo, A., Lowe, D., Bolognesi C., Fabbri, E., Koehler, A., 2007. The use of biomarkers in biomonitoring: A 2-tier approach assessing the level of pollutantinduced stress syndrome in sentinel organisms. Comp. Biochem. Physiol. C 146, 281300.

Voutsinou-Taliadouri, F., Varnavas, S.P., 1993. Geochemical study of sediments from northern Euboekos Bay, Greece, with regard to the presence of submarine mineral deposits. Mar. Geol. 110, 93-114.

Walker, C.H., Hopkin, S.P., Sibly, R.M., Peakal, D.B., 2006. Principles of Ecotoxicology, CRC Presss, Taylor \& Francis Group, Boca Raton.

Wo, K.T., Lam P.K.S., Wu, R.S.S., 1999. A comparison of growth biomarkers for assessing sublethal effects of cadmium on a marine gastropod, Nassarius festivus. Mar. Pollut. Bull. 39, 165-173.

Zenetos, A., Hatzianestis, I., Lantzouni, M., Simboura, M., Sklivagou, E., Arvanitakis, G. 2004. The Eurobalker oil spill: mid-term changes of some ecosystem indicators. Mar. Pollut. Bull. 48, 122-131. 
Table 1. Sampling sites in Greek coastal areas, types of anthropogenic impacts and levels of pollutants reported in sediments in the selected areas (AHC: aliphatic hydrocarbons, PAH: polycyclic aromatic hydrocarbons, DDTs: sum of DDT, DDD, DDE, PCBs: polychlorinated biphenyls (sum of 11 congeners)).

\begin{tabular}{|c|c|c|c|c|c|c|c|c|c|c|c|c|}
\hline \multirow[t]{2}{*}{ Station } & \multirow{2}{*}{$\begin{array}{l}\text { Longitude } \\
\text { and latitude }\end{array}$} & \multirow[t]{2}{*}{ Area } & \multirow[t]{2}{*}{ Type of anthropogenic impact } & \multicolumn{9}{|c|}{ Pollutant concentrations in sediments } \\
\hline & & & & $\begin{array}{l}\mathrm{AHC} \\
\mu \mathrm{g} / \mathrm{g}\end{array}$ & $\begin{array}{l}\mathrm{PAH} \\
\mathrm{ng} / \mathrm{g}\end{array}$ & $\begin{array}{l}\text { DDTs } \\
\mathrm{ng} / \mathrm{g}\end{array}$ & $\begin{array}{c}\text { PCBs } \\
\mathrm{ng} / \mathrm{g}\end{array}$ & $\begin{array}{c}\mathrm{Pb} \\
\mu \mathrm{g} / \mathrm{g}\end{array}$ & $\begin{array}{c}\mathrm{Cu} \\
\mu g / \mathrm{g}\end{array}$ & $\begin{array}{c}\mathrm{Zn} \\
\mu \mathrm{g} / \mathrm{g}\end{array}$ & $\begin{array}{c}\mathrm{Cr} \\
\mu \mathrm{g} / \mathrm{g}\end{array}$ & $\begin{array}{c}\mathrm{Ni} \\
\mu \mathrm{g} / \mathrm{g}\end{array}$ \\
\hline S1 & $\begin{array}{l}22^{\circ} 53.56^{\prime} \mathrm{E} \\
40^{\circ} 36.07^{\prime} \mathrm{N}\end{array}$ & Thermaikos Gulf & $\begin{array}{l}\text { Urban wastes from } \\
\text { Thessalonica, industrial inputs }\end{array}$ & $1100^{a}$ & $1160^{\mathrm{a}}$ & $7.1^{\mathrm{a}}$ & $11.4^{\mathrm{a}}$ & $146^{b}$ & $67^{b}$ & $221^{b}$ & $287^{b}$ & \\
\hline $\mathrm{S} 2$ & $\begin{array}{l}22^{\circ} 43.72^{\prime} \mathrm{E} \\
40^{\circ} 29.37^{\prime} \mathrm{N}\end{array}$ & Thermaikos Gulf & $\begin{array}{l}\text { Urban wastes from } \\
\text { Thessalonica, industrial } \\
\text { inputs, agricultural practices }\end{array}$ & $106^{\mathrm{a}}$ & $218^{a}$ & $1.9^{\mathrm{a}}$ & $0.9^{\mathrm{a}}$ & $369^{b}$ & $17^{b}$ & $26^{b}$ & $231^{b}$ & \\
\hline S3 & $\begin{array}{l}23^{\circ} 42.88^{\prime} \mathrm{E} \\
37^{\circ} 52.56^{\prime} \mathrm{N}\end{array}$ & Saronikos Gulf & $\begin{array}{l}\text { Urban wastes from Athens, } \\
\text { industrial inputs }\end{array}$ & $136^{\mathrm{c}}$ & $2270^{c}$ & $2.1^{\mathrm{d}}$ & $5.3^{d}$ & $22^{\mathrm{c}}$ & $8^{c}$ & $42^{\mathrm{c}}$ & $63^{c}$ & $34^{c}$ \\
\hline S4 & $\begin{array}{l}23^{\circ} 19.30^{\prime} \mathrm{E} \\
38^{\circ} 35.28^{\prime} \mathrm{N}\end{array}$ & N. Evoikos Gulf & $\begin{array}{l}\text { Industrial inputs by ferronickel } \\
\text { production, metalifferous slag } \\
\text { disposal }\end{array}$ & $31^{e}$ & $7760^{f}$ & $0.45^{\mathrm{e}}$ & $8.8^{\mathrm{e}}$ & $24^{e}$ & $14^{\mathrm{e}}$ & $100^{e}$ & $15000^{e}$ & $900^{e}$ \\
\hline S5 & $\begin{array}{l}23^{\circ} 44.28^{\prime} \mathrm{E} \\
38^{\circ} 20.67^{\prime} \mathrm{N}\end{array}$ & S. Evoikos Gulf & $\begin{array}{l}\text { Industrial inputs via Asopos } \\
\text { river }\end{array}$ & $31^{g}$ & $7760^{g}$ & & & $27^{\mathrm{h}}$ & $42^{\mathrm{h}}$ & $106^{h}$ & $404^{h}$ & $671^{\mathrm{h}}$ \\
\hline S6 & $\begin{array}{l}22^{\circ} 35.98^{\prime} \mathrm{E} \\
38^{\circ} 19.46^{\prime} \mathrm{N} \\
\end{array}$ & Korinthiakos Gulf & $\begin{array}{l}\text { Industrial inputs by alumina } \\
\text { production, red mad disposal }\end{array}$ & $18^{b}$ & $4330^{b}$ & $0.4^{b}$ & $19.1^{b}$ & $91^{b}$ & $32^{b}$ & $72^{b}$ & $1820^{b}$ & $850^{b}$ \\
\hline S7 & $\begin{array}{l}22^{\circ} 37.23^{\prime} \mathrm{E} \\
38^{\circ} 52.23^{\prime} \mathrm{N}\end{array}$ & Maliakos Gulf & & $12^{i}$ & $140^{i}$ & & & $37^{j}$ & $43^{j}$ & $105^{j}$ & & $220^{j}$ \\
\hline S8 & $\begin{array}{l}22^{\circ} 1.08^{\prime} \mathrm{E} \\
37^{\circ} 0.14^{\prime} \mathrm{N}\end{array}$ & Messiniakos Gulf & $\begin{array}{l}\text { Agricultural practices, urban } \\
\text { wastes }\end{array}$ & $18^{\mathrm{k}}$ & $120^{\mathrm{k}}$ & & & $30^{\mathrm{k}}$ & $43^{k}$ & $70^{\mathrm{k}}$ & $149^{\mathrm{k}}$ & $96^{\mathrm{k}}$ \\
\hline S9 & $\begin{array}{l}20^{\circ} 42.02^{\prime} \mathrm{E} \\
38^{\circ} 58.09^{\prime} \mathrm{N}\end{array}$ & $\begin{array}{l}\text { Entrance of } \\
\text { Amvrakikos Gulf }\end{array}$ & & $29^{1}$ & $480^{1}$ & $0.23^{1}$ & $0.33^{1}$ & & & & & \\
\hline S10 & $\begin{array}{l}23^{\circ} 13.02^{\prime} \mathrm{E} \\
39^{\circ} 10.47^{\prime} \mathrm{N}\end{array}$ & Pagassitikos Gulf & Agricultural and aquaculture & $14^{\mathrm{b}}$ & $138^{b}$ & $1.7^{b}$ & $0.9^{b}$ & $44^{b}$ & $41^{b}$ & $124^{b}$ & $267^{b}$ & $270^{b}$ \\
\hline S11 & $\begin{array}{l}25^{\circ} 14.06^{\prime} \mathrm{E} \\
40^{\circ} 53.29^{\prime} \mathrm{N}\end{array}$ & $\begin{array}{l}\text { Broader Nestos river } \\
\text { estuary }\end{array}$ & practices & $28^{\mathrm{m}}$ & $310^{\mathrm{m}}$ & $3.1^{\mathrm{m}}$ & $1.9^{\mathrm{m}}$ & & & & & \\
\hline
\end{tabular}


Table 1 continued

\begin{tabular}{|c|c|c|c|c|c|c|c|c|c|c|c|c|}
\hline \multirow[t]{2}{*}{ Station } & \multirow{2}{*}{$\begin{array}{l}\text { Longitude } \\
\text { and latitude }\end{array}$} & \multirow[t]{2}{*}{ Area } & \multirow[t]{2}{*}{ Type of anthropogenic impact } & \multicolumn{9}{|c|}{ Pollutant concentrations in sediments } \\
\hline & & & & $\begin{array}{l}\mathrm{AHC} \\
\mu \mathrm{g} / \mathrm{g}\end{array}$ & $\begin{array}{l}\mathrm{PAH} \\
\mathrm{ng} / \mathrm{g}\end{array}$ & $\begin{array}{c}\text { DDTs } \\
\mathrm{ng} / \mathrm{g}\end{array}$ & $\begin{array}{c}\text { PCBs } \\
\mathrm{ng} / \mathrm{g}\end{array}$ & $\begin{array}{c}\mathrm{Pb} \\
\mu \mathrm{g} / \mathrm{g}\end{array}$ & $\begin{array}{c}\mathrm{Cu} \\
\mu \mathrm{g} / \mathrm{g}\end{array}$ & $\begin{array}{c}\mathrm{Zn} \\
\mu \mathrm{g} / \mathrm{g}\end{array}$ & $\begin{array}{c}\mathrm{Cr} \\
\mu \mathrm{g} / \mathrm{g}\end{array}$ & $\begin{array}{c}\mathrm{Ni} \\
\mu \mathrm{g} / \mathrm{g}\end{array}$ \\
\hline S12 & $\begin{array}{l}24^{\circ} 53.62^{\prime} \mathrm{E} \\
40^{\circ} 53.45^{\prime} \mathrm{N} \\
\end{array}$ & Nestos river estuary & $\begin{array}{l}\text { Agricultural and aquaculture } \\
\text { practices }\end{array}$ & $36^{\mathrm{m}}$ & $280^{\mathrm{m}}$ & $16.7^{\mathrm{m}}$ & $1.8^{\mathrm{m}}$ & $71^{b}$ & $15^{b}$ & $102^{b}$ & $51^{b}$ & \\
\hline S13 & $\begin{array}{l}25^{\circ} 20.54^{\prime} \mathrm{E} \\
36^{\circ} 21.94^{\prime} \mathrm{N}\end{array}$ & $\begin{array}{l}\text { Santorini island, } \\
\text { Aegean Sea }\end{array}$ & $\begin{array}{l}\text { Shipwreck of cruise ship 'Sea } \\
\text { Diamond' in April } 2007\end{array}$ & $8^{n}$ & $33^{n}$ & & & $34^{\circ}$ & $26^{\circ}$ & $69^{\circ}$ & $20^{\circ}$ & $17^{0}$ \\
\hline S14 & $\begin{array}{l}24^{\circ} 5.01 ' \mathrm{E} \\
39^{\circ} 21.38^{\prime} \mathrm{N} \\
\end{array}$ & $\begin{array}{l}\text { Alonissos island, } \\
\text { Aegean Sea }\end{array}$ & Natural park & & & & & & & & & \\
\hline S15 & $\begin{array}{l}26^{\circ} 33.32^{\prime} \mathrm{E} \\
39^{\circ} 0.11^{\prime} \mathrm{N}\end{array}$ & $\begin{array}{l}\text { Lesvos island, } \\
\text { Aegean Sea }\end{array}$ & & & & & & & & & & \\
\hline S16 & $\begin{array}{l}28^{\circ} 13.54^{\prime} \mathrm{E} \\
36^{\circ} 27.47^{\prime} \mathrm{N}\end{array}$ & $\begin{array}{l}\text { Rodhes island, } \\
\text { Aegean Sea }\end{array}$ & $\begin{array}{l}\text { Tourist area, absence of } \\
\text { known pollution sources }\end{array}$ & $10^{\mathrm{p}}$ & $20^{p}$ & $0.14^{\mathrm{p}}$ & $1.3^{\mathrm{p}}$ & $6^{p}$ & $47^{p}$ & $83^{p}$ & $960^{p}$ & $500^{p}$ \\
\hline S17 & $\begin{array}{l}25^{\circ} 24.01^{\prime} \mathrm{E} \\
36^{\circ} 58.15^{\prime} \mathrm{N} \\
\end{array}$ & $\begin{array}{l}\text { Naxos island, Aegean } \\
\text { Sea }\end{array}$ & & & & & & & & & & \\
\hline S18 & $\begin{array}{l}24^{\circ} 6.11^{\prime} \mathrm{E} \\
34^{\circ} 48.24^{\prime} \mathrm{N}\end{array}$ & $\begin{array}{l}\text { Gaydos island, } \\
\text { Aegean Sea }\end{array}$ & $\begin{array}{l}\text { Absence of known pollution } \\
\text { sources }\end{array}$ & & & & & & & & & \\
\hline
\end{tabular}

${ }^{a}$ HCMR, 2008a, b Laboratory Network of the Environmental Quality monitoring of the Hellenic Seas, 2006, ${ }^{\mathrm{c}}$ Karageorgis and Hatzianestis, 2003, ${ }^{\mathrm{d}}$ Hatzianestis and Botsou, 2005, ${ }^{\mathrm{e}}$ HCMR, 2008b, ${ }^{\mathrm{f}}$ Hatzianestis et al., 2005, ${ }^{\mathrm{g}}$ Zenetos et al., 2004, ${ }^{\mathrm{i}}$ Hatzianestis, unpublished results, ${ }^{\mathrm{j}}$ Anagnostou and Kaberi, 1995, ${ }^{\mathrm{k}}$ HCMR, 2007a, ${ }^{l}$ Lelekis et al, 2001, ${ }^{\mathrm{m}}$ Cotou et al., 2002, ${ }^{\mathrm{n}}$ HCMR, 2007b, ${ }^{\circ} \mathrm{HCMR}, 2008 \mathrm{c},{ }^{\mathrm{p}}$ HCMR, 2004. 
Table 2. Concentrations of RNA and DNA in mussels caged for three months at 18 sites in Greek coastal waters (mean \pm standard error, $n=3$ ) used for the calculation of RNA:DNA ratio.

\begin{tabular}{lcc}
\hline & RNA & DNA \\
& ng/mg & ng/mg \\
\hline Thessaloniki & $2.1 \pm 0.1$ & $158.5 \pm 2.7$ \\
Axios & $5.1 \pm 0.1$ & $206.2 \pm 6.7$ \\
Ag. Kosmas & $17.6 \pm 0.2$ & $119.0 \pm 0.9$ \\
Larymna & $148.5 \pm 0.2$ & $63.4 \pm 0.2$ \\
Asopos & $154.7 \pm 0.3$ & $89.67 \pm 0.8$ \\
Korinthiakos & $10.0 \pm 0.5$ & $121.0 \pm 0.1$ \\
Maliakos & $4.1 \pm 0.1$ & $248.0 \pm 1.3$ \\
Milina & $85.8 \pm 0.2$ & $248.9 \pm 3.1$ \\
Kalamata & $184.0 \pm 0.6$ & $152.8 \pm 0.6$ \\
Preveza & $308.9 \pm 15.5$ & $310.5 \pm 11.1$ \\
Fanari & $5.8 \pm 0.1$ & $117.6 \pm 1.4$ \\
Nestos & $4.2 \pm 0.2$ & $216.3 \pm 2.1$ \\
Santorini & $67.1 \pm 0.4$ & $238.3 \pm 2.7$ \\
Alonisos & $86.7 \pm 1.0$ & $261.7 \pm 1.6$ \\
Lesvos & $59.7 \pm 0.3$ & $107.9 \pm 0.9$ \\
Rodos & $6.95 \pm 0.1$ & $116.8 \pm 0.6$ \\
Naxos & $172.6 \pm 6.9$ & $134.6 \pm 0.4$ \\
Gavdos & $82.8 \pm 0.2$ & $89.1 \pm 0.6$ \\
\hline
\end{tabular}

Table 3. PCA: Component loadings of the variables for PC1, PC2 and PC3.

\begin{tabular}{llcc}
\hline Variables & PC1 & PC2 & PC3 \\
\hline AchE & -0.639 & -0.026 & 0.045 \\
CAT & -0.241 & -0.585 & -0.260 \\
GST & -0.395 & 0.079 & -0.599 \\
MTs & -0.211 & 0.628 & 0.316 \\
RNA:DNA & 0.019 & -0.505 & 0.578 \\
Condition index & 0.578 & 0.027 & -0.372 \\
\hline
\end{tabular}

Significant correlation coefficients are in italics 


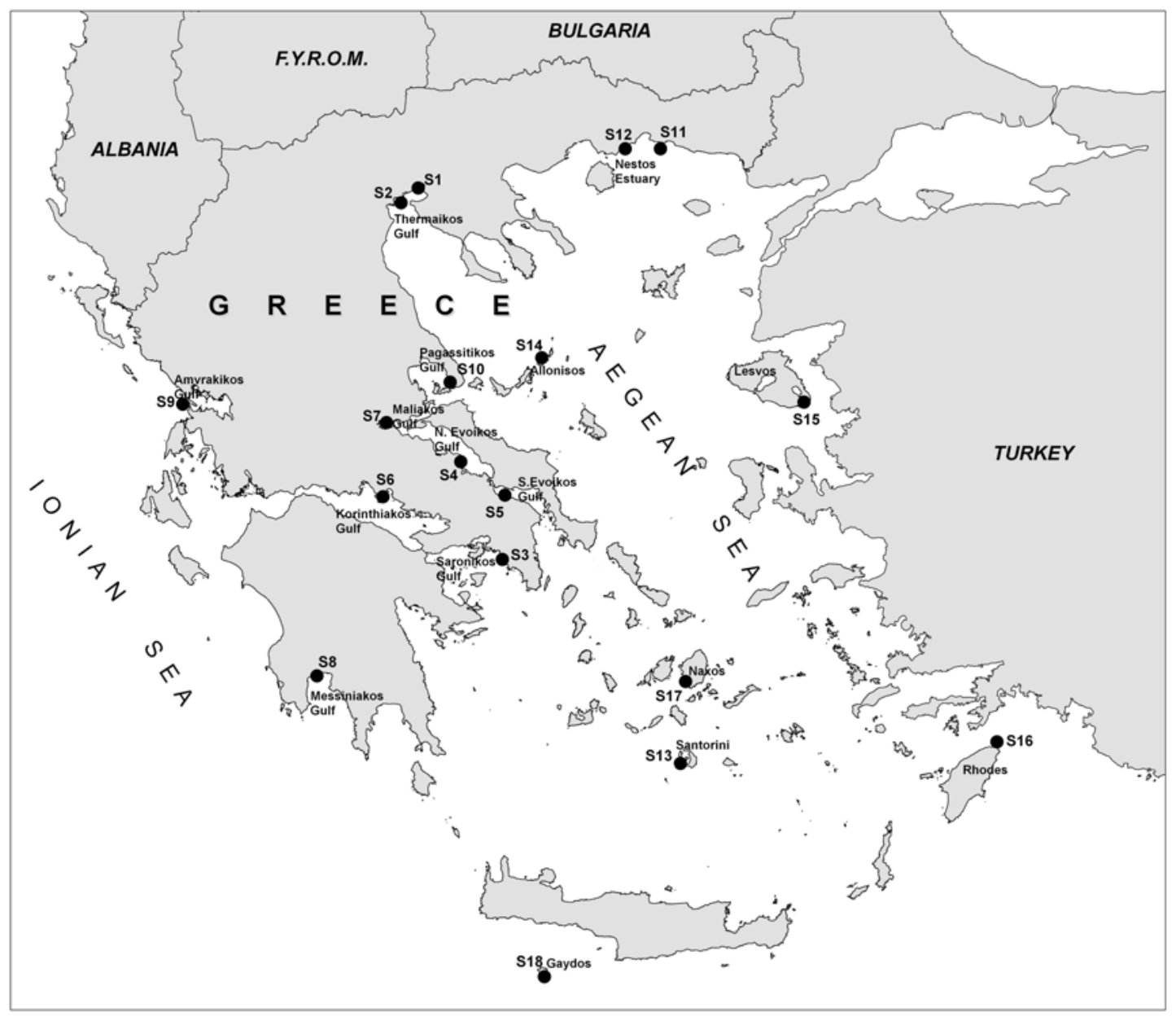

Figure 1. Location of the 18 sampling sites in the Greek coastal region. 


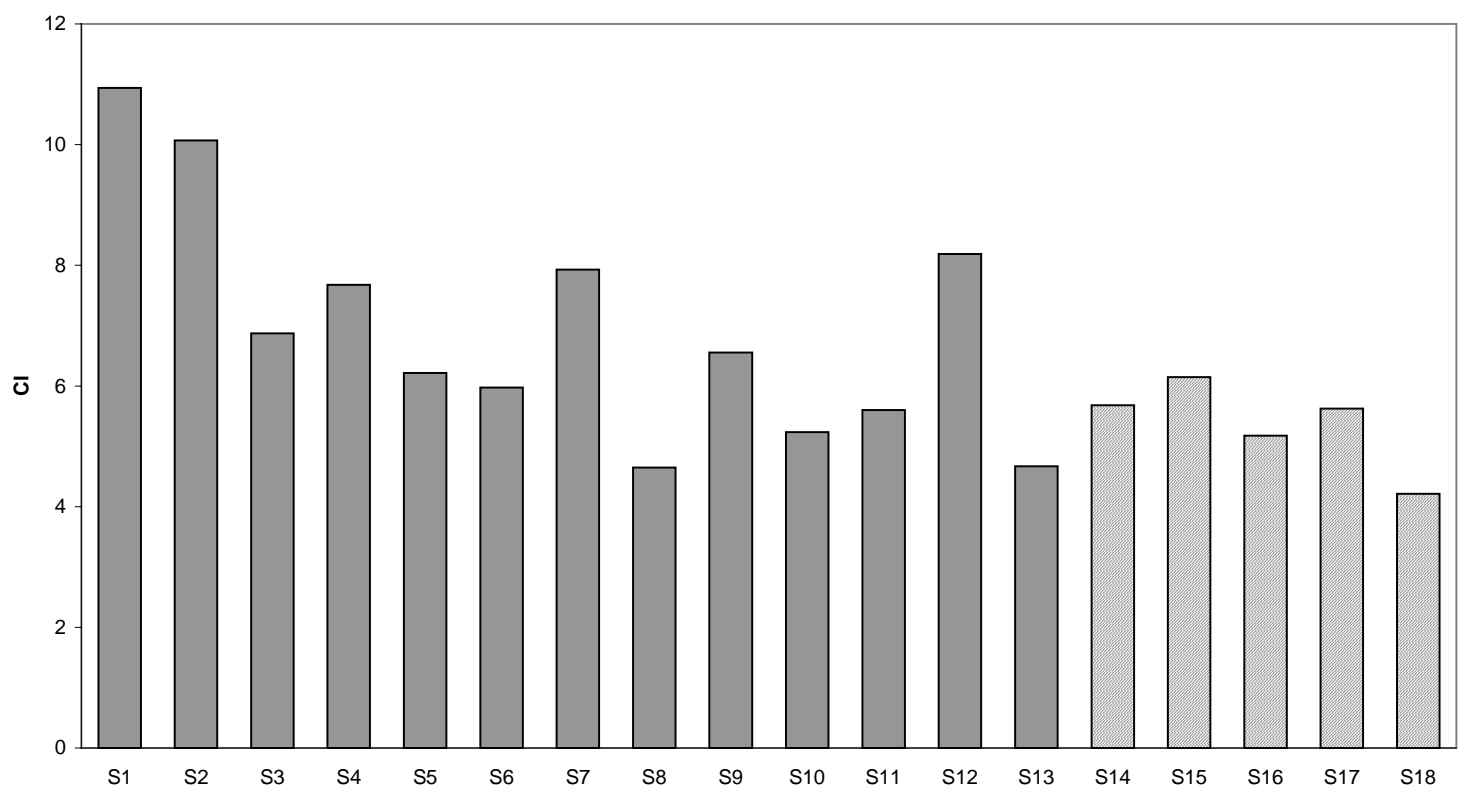

Figure 2. Condition index (C.I.) of mussels $M$. galloprovincialis caged for three months at 18 sites in Greek coastal waters (30-40 pooled individuals per site). Dashed bars represent reference sites.

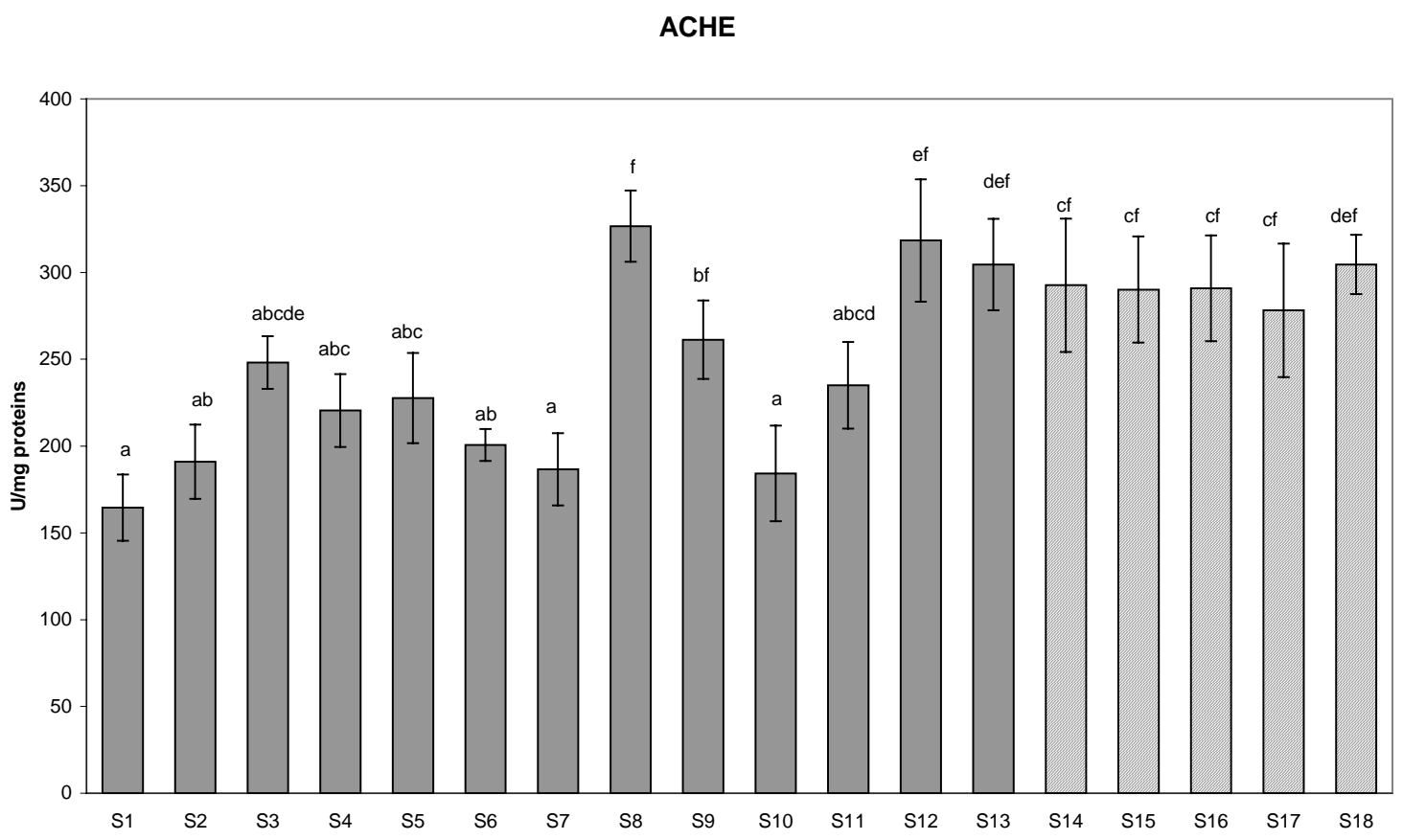

Figure 3. Acetylcholinesterase (AchE) activities (U/mg proteins) in the gills of mussels $M$. galloprovincialis caged for three months at 18 sites in Greek coastal waters. Dashed bars represent reference sites.

Mean \pm standard error, $n=5$.

Bars without a common letter are significantly different (Fisher's LSD test, $\mathrm{P}<0.05$ ). 


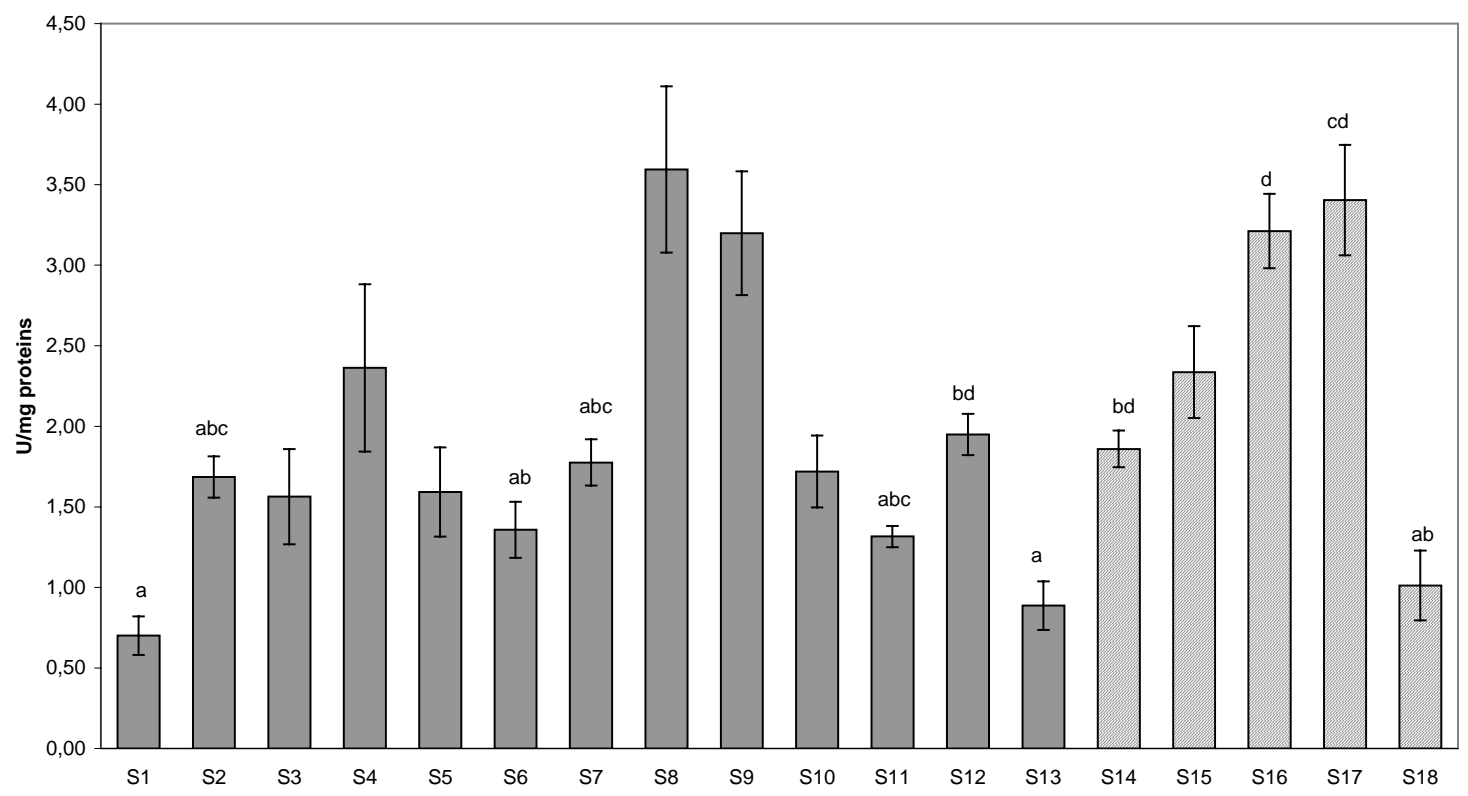

Figure 4. Catalase (CAT) activities (U/mg proteins) in the digestive gland of mussels $M$. galloprovincialis caged for three months at 18 sites in Greek coastal waters. Dashed bars represent reference sites.

Mean \pm standard error, $n=5$.

Bars without a common letter are significantly different (Games-Howell test, $\mathrm{P}<0.05$ ); bars without letters show no significant differences.

GST

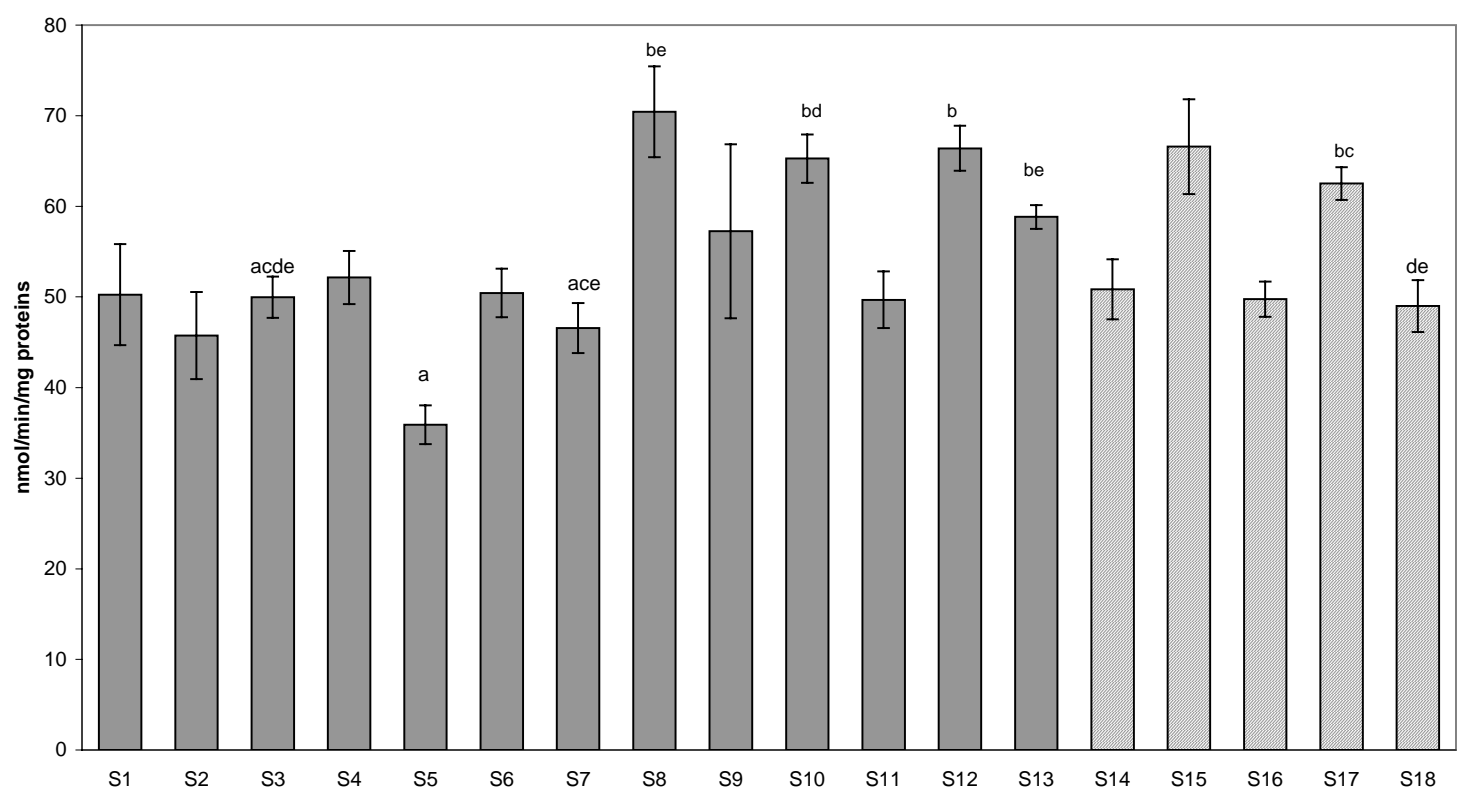

Figure 5. Glutathione-S-Transferase (GST) activities (nmol conjugate/min/mg proteins) in the digestive gland of mussels $M$. galloprovincialis caged for three months at 18 sites in Greek coastal waters. Dashed bars represent reference sites. Mean \pm standard error, $\mathrm{n}=5$.

Bars without a common letter are significantly different (Games-Howell test, $\mathrm{P}<0.05$ ); bars without letters show no significant differences. 


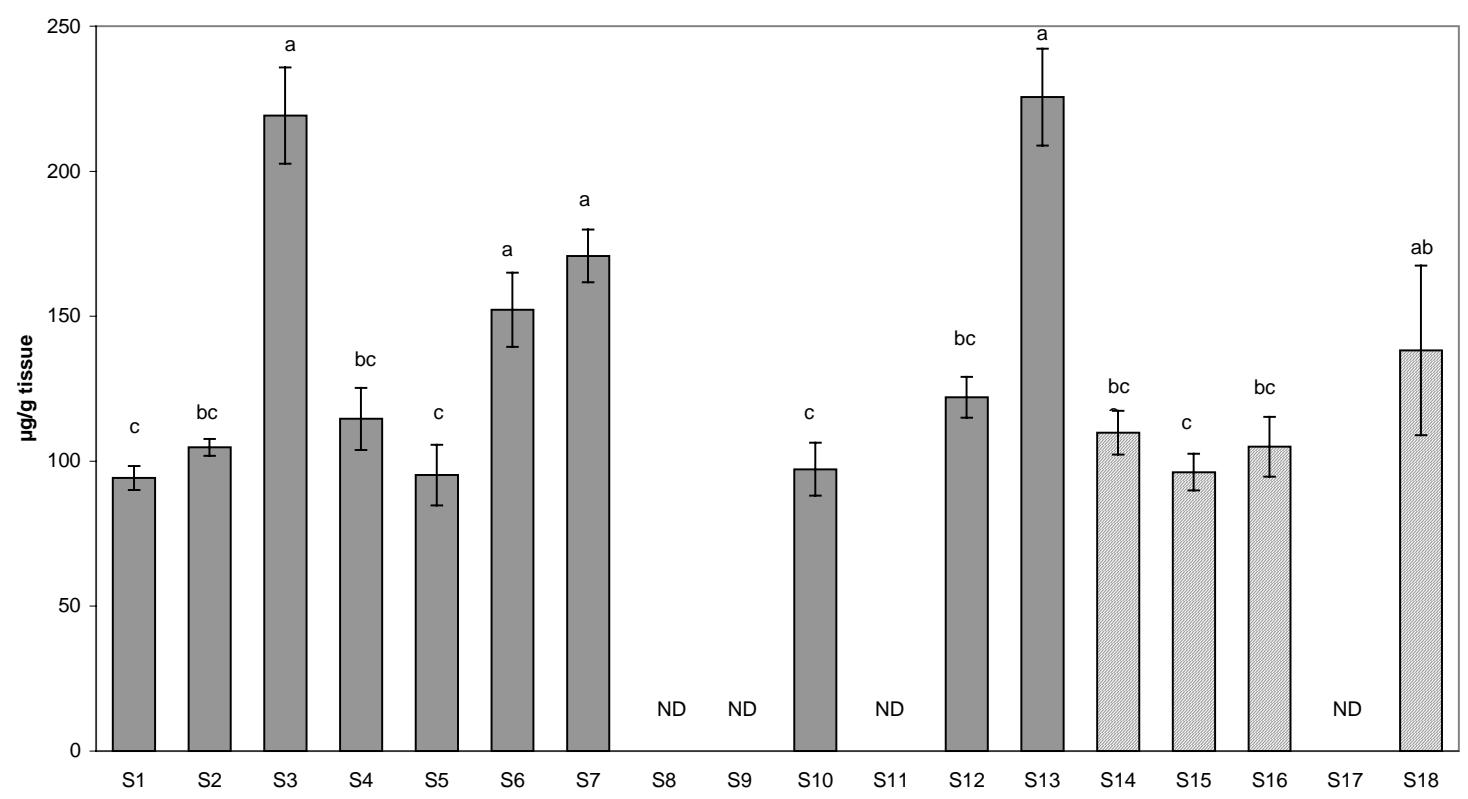

Figure 6. Metallothionein (MTs) levels ( $\mu \mathrm{g} / \mathrm{g}$ tissue) in the digestive gland of mussels M. galloprovincialis caged for three months at 18 sites in Greek coastal waters. Dashed bars represent reference sites. ND: no data.

Mean \pm standard error, $n=5$.

Bars without a common letter are significantly different (Fisher's LSD test, $\mathrm{P}<0.05$ ).

RNA:DNA

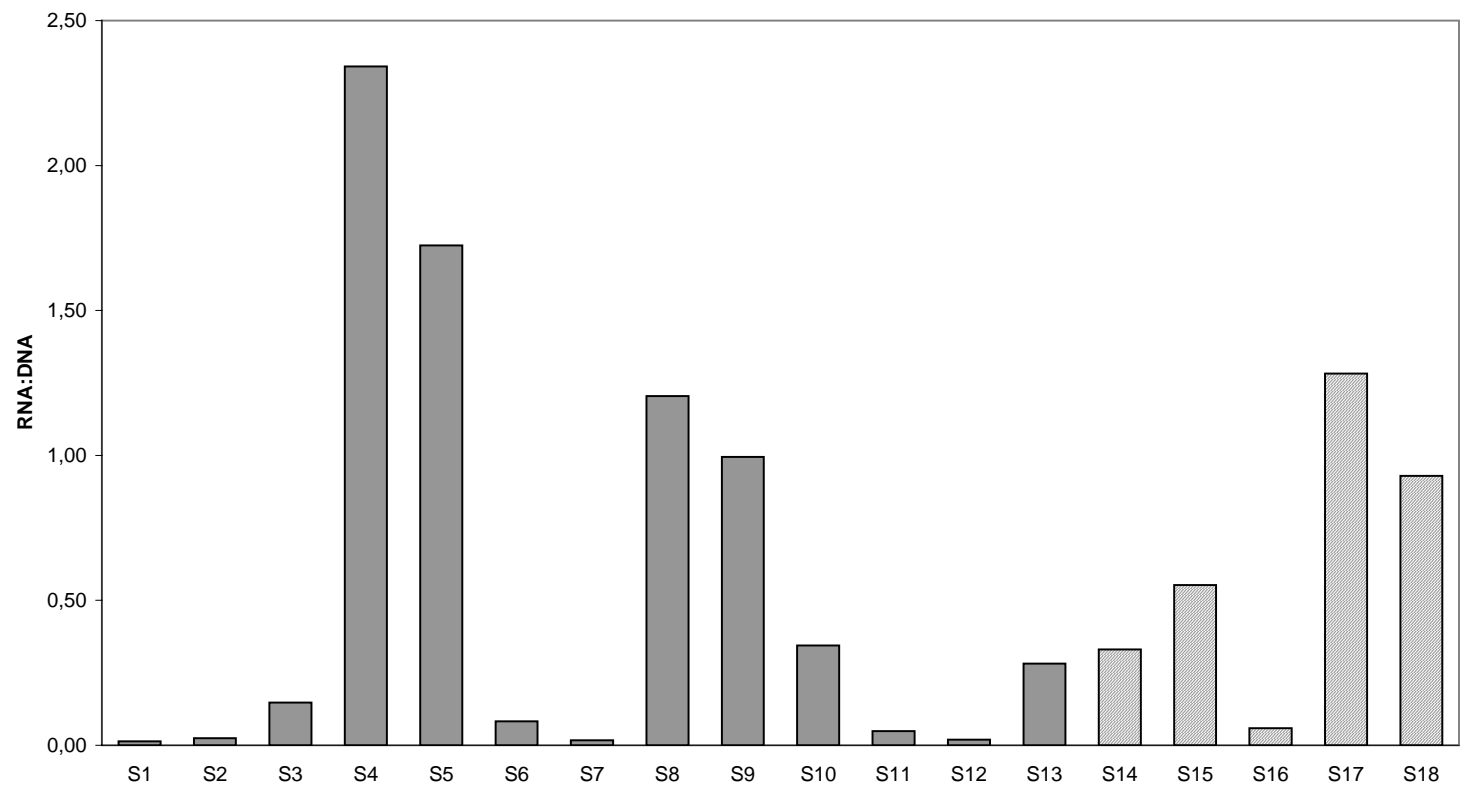

Figure 7. RNA:DNA ratio in whole soft tissues of mussels $M$. galloprovincialis caged for three months at 18 sites in Greek coastal waters. Dashed bars represent reference sites. RNA:DNA is calculated as the ratio of mean RNA concentrations ( $\mathrm{ng} / \mathrm{mg})(\mathrm{n}=3)$ to mean DNA concentrations $(\mathrm{ng} / \mathrm{mg})(\mathrm{n}=3)$ at each site. 
A.

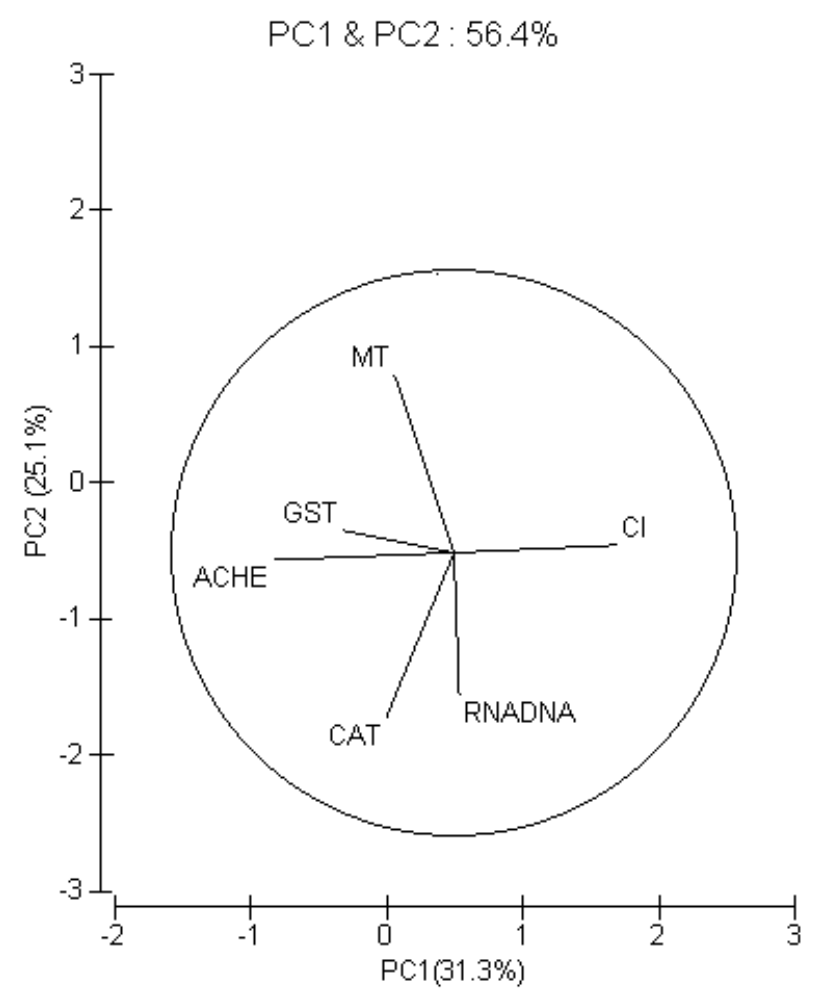

B.

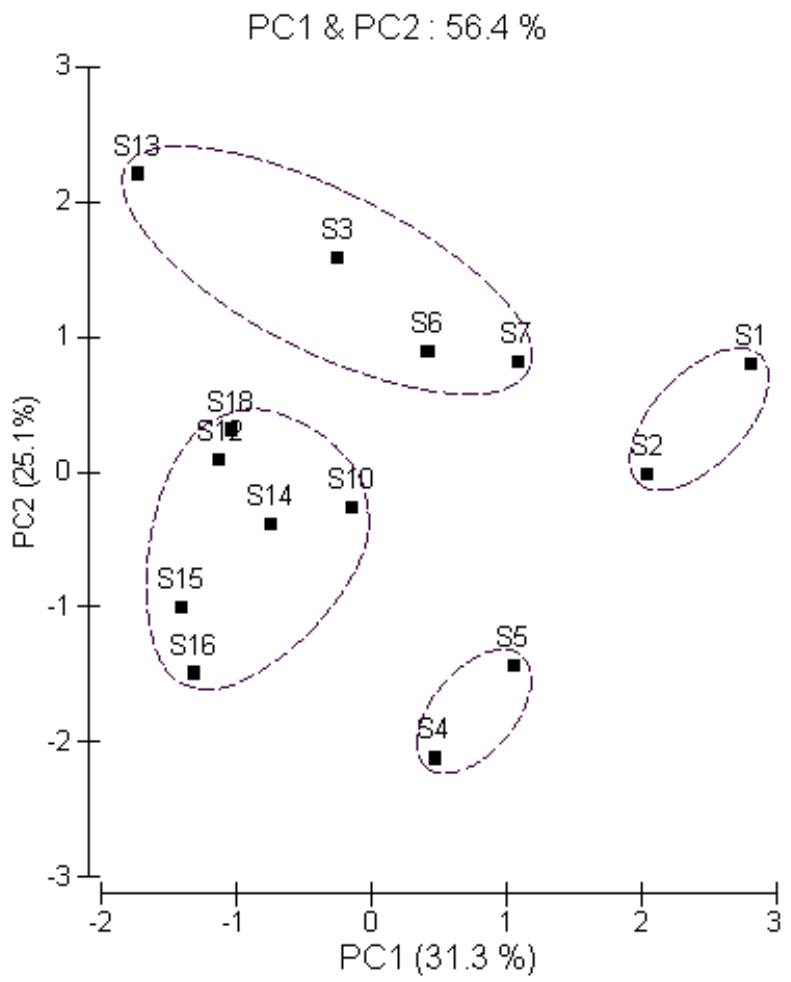

Figure 8. Results of the PCA of the two dominant components produced by biomarkers (AchE, MTs, CAT, GST) and condition index (CI). (A) Plot of variable vectors. (B) Plot of scores of different sites. 